\title{
Analysis of Mathematical Communication Skills Students for Two Variable Linear Equation Systems Material
}

\author{
Meli Susanti, Anisa Nurul Hasinah, Luvy Sylviana Zanthy \\ Pendidikan Matematika, Pendidikan Matematika dan Sains, IKIP Siliwangi \\ e-mail:meli16510200@gmail.com
}

\begin{abstract}
The communication skills of eighth grade junior high school students are catergorized as low. The purpose of this study is to analyze and describe aspects of mathematical communication skill, the research subjects consisted of 10 class students in one of the private schools located in Cimahi. The research method with data collection techniques. From the descript test regarding the two variabel linear equation system of 4 question. The results of this study indicated that students mathematical communication skill are categorized as moderate with a percentage of $42.5 \%$ with the percentage of each item, number one $47.5 \%$, question number two $60 \%$, and question number four $32.5 \%$.
\end{abstract}

Keywords: Error analysis; Communication skill; Two variable linear equation.

\section{INTRODUCTION}

Mathematics is a science that has an important role in the world of education, because mathematics is a means to shapes students to think scientifically according to Hendra (Andayani, 2019). Mathematics is important both as a tool and as a science according to Ruseffendi (Zanthy, 2016). In addition to learning mathematics, children's abilities will be more develoved and trained, like Suherman opinion (Purwasih, 2015). There are 13 Mathematical abilities, namely understanding understanding, connection, investigation, communication, observation, exploration, inquiry conjecture, hypothesis, generalization of creativity and problem solving. So learning mathematics is required from elementary school to tertiary education with the aim to equip and prepare students to continue the nation's generation. One of the abilities of students that must be possessed and become the basic capital in learning is mathematical communications skills. According to the ministry of National Education (Wijayanto, Fajriah, \& Anita, 2018) one of the goals of learning mathematics in schools is that students have the ability to communicate ideas with language and written mathematics to clarify the situation or problem.

Communication skills include the ability to express situations, ideas, into mathematical language, symbols, graphs, and mathematical models that are able to read and explain and hear an argument itself that aims to solve everyday problems contained in mathematics itself, according to Martini, et. al (2018). The importance of communication skills in learning mathematics for students, namely to sharpen ways of thinking, as an appraisal assessment tool, help build knowledge, and improve problem solving skills, according to Asikin (Wijayanto, Fajriah, \& Anita, 2018). Besides that, with communication skills students are able to reflect ideas, improve, discuss and develop, so that when students try to write they are trying to explain and convince, According to Yuniarti, et. al (2018). Therefore, communication skills play an important role in 
mathematics learning. The indicators of mathematical communication skills include: (1) Connecting reals objects, draw state of mathematical symbols (2) State everyday conditions in mathematical modeling (3) Explain ideas, draw symbols with writing(4) Listen and write about mathematic, (5) Making conjectures, formulating definitions and generalization, according Sumarmo (Yuniarti et al., 2018)

Based on the results of observations and interviews of reserchers in the field with one of the mathematics teachers in Cimahi city SMP revealed that students mathematical communication skills are still categorized as low, students still feel difficulties and make mistakes when expressing modeling in mathematics with story problems, seen from the results of daily tests of students on SPLDV grade VII material, revealed that the level of students ability to understand and express mathematical modeling into situation. Based on Rahmawati, et. al (2018) research results show that students communication skills are still low, seen from the results of communication skills test answers, students still make mistakes explaining ideas or situation into mathematical modeling, picture or graphics, and expressing it into everyday situation, the percentage obtained from the situation is less than $33 \%$.

According to Farida (Hajar \& Zanthy, 2008), when solving math problems errors can occur which can be used in detecting mathematics learning difficulties so students can find ways to solve when solving mathematical story problems. As Abdurrahman's (putri, 2018) opinion learning achievement is influenced by two factors, namely internal and external factors. The internal factors are the lack of selfsupport such as interests and talents while the external factors can be from the environment where students associate with the teacher and curriculum. In line with what was revealed by Sukardi (Rahayu, Purnomo, \& Sukidin, 2014), the guidelines that need to be considered by the teacher in compiling questions given to students are the problems or problems stated in the form of statements and making and making alternative answers to four alternatives, where there is one correct answer as the key to this answer due to because teachers only use the usual approach or general approach, the lack of understanding of communication in students. According to Djemari Mardapi (Wijayanto, Fajriah \& Anita, 2018) that efforts to improve the quality of education can be pursued through improving the quality of learning and assessment systems.

\section{RESEARCH METHOD}

The research method used in this research is descriptive qualitative reseaarch. According Arikunto (Sari, Susanti, \& Rahayu, 2018) states that descriptive research is research that describes a thing, while qualitative research is obtained from numbers, words, symbols or image. So descriptive qualitative research is research that describes a thing with words, numbers or image.

The research carried out aims to analyze and describe students mathematical communication skills in answering each of the four question test items. The subjects of this study were 10 students of class VIII at SMP IT Budi Luhur located in Cimahi city. The research location is determined intentionally and the object of this study is based on the problems found in fact, namely the low level of communication understanding obtained at the time of the instrument test problem

The research was conducted in three stages, that is; (1) Preparation stage, at this stage the research compiles the test instrument and guidance with the research supervisor, determines the sample and place of research (2) Implementation phase, at the implementation stage which is carrying out the test instrument to students (3) Evaluation 
stage, researchers collect and process data and prepare reports. Data collection techniques on scoring mathematical communication skills of students according to Soemarmo (Rahmawati, Bernard \& Akbar, 2018):

Table 1 Guidelines for scoring communication skills

\begin{tabular}{cl}
\hline Scor & \multicolumn{1}{c}{ Criteria } \\
\hline 4 & $\begin{array}{l}\text { A complete and clear response, no doubt, complete diagram, efficient communication, } \\
\text { logical presentation, accompanied by examples }\end{array}$ \\
\cline { 2 - 2 } 3 & $\begin{array}{l}\text { Correct and complete responses, complete diagrams, efficient communication, and } \\
\text { complete presentation, but not included example }\end{array}$ \\
\cline { 2 - 2 } 2 & $\begin{array}{l}\text { Correct responses are complete and clear, complete diagrams, communication and } \\
\text { presentation are incomplete, and are not accompanied by example }\end{array}$ \\
\cline { 2 - 2 } 1 & $\begin{array}{l}\text { The response is correct but incomplete/unclear, diagrams, communication and presentation } \\
\text { are incomplete, and are not accompanied by examples }\end{array}$ \\
\cline { 2 - 2 } 0 & Response, inefficient communication, misinterpretation (blank answer sheet or no answer) \\
\hline
\end{tabular}

Table 2 Category of achievement of student' mathematical communication skill

\begin{tabular}{cc}
\hline Achievement of mathematical communication & Category \\
skill & \\
\hline $33 \%$ & Low \\
$>33 \%$ & Medium \\
$>66 \%$ & High \\
\hline
\end{tabular}

Based on the ability scoring table and its category the researcher is able to provide an assessment properly and correctly in accordance with the ability indicators possessed by students

\section{RESULTS AND DISCUSSION}

Based on the results of the analysis of student answers carried out againt VII grade students as many 10 students we can see in the table below :

Tabel 3 Presentase Kemampuan Komunikasi Matematis

\begin{tabular}{ccccc}
\hline \multirow{2}{*}{ Student code } & \multicolumn{4}{c}{ Scor } \\
\cline { 2 - 5 } & question 1 & question 2 & question 3 & question 4 \\
\hline A1 & 2 & 3 & 2 & 0 \\
A2 & 1 & 3 & 1 & 0 \\
A3 & 0 & 2 & 1 & 0 \\
A4 & 1 & 2 & 2 & 2 \\
A5 & 0 & 1 & 2 & 0 \\
A6 & 1 & 1 & 0 & 0 \\
A7 & 4 & 4 & 3 & 4 \\
A8 & 4 & 2 & 0 & 0 \\
A9 & 4 & 4 & 3 & 2 \\
A10 & 2 & 2 & 0 & 12 \\
\hline Total score of & & & & \\
items for many & 19 & 24 & 13 & $30 \%$ \\
students x & & & & \\
maximu m scor & & & & \\
\hline Item percentage & $47.5 \%$ & & & \\
\hline
\end{tabular}


Based on the percentage table of students mathematical communication skills, it can be seen the acquisition of the value of the ability of each item and the percentage of mathematical communication skills of students viewed from the results of the ability test. At number 1 , the percentage of students mathematical communication skills by $47.5 \%$ shows that the students mathematical communication skills in solving problems in problem number one is $33 \%$ greater, stating that students have medium level mathematical communication skills. In number 2 the percentage of students mathematical communication skills by $60 \%$ shows that the students' mathematical communication abilities, to solve the problems contained in number 2 is greater than $33 \%$ shows that the students' mathematical commercialization ability in solving problems contained in questions number 2 is of medium level. The percentage of students mathematical communication skills in question number 3 of $32.5 \%$ shows that the percentage obtained is less than $33 \%$, it means the students mathematical communication ability in solving problems contained in problem number 3 in mathematical communication skills is categorized as low. In question number 4 students mathematical communication skills students get a percentage of $30 \%$, it means the students ability is less than $33 \%$ means that the student's mathematical ability to solve problems contained in problem number four is still categorized as low. The following are some views of student answers.

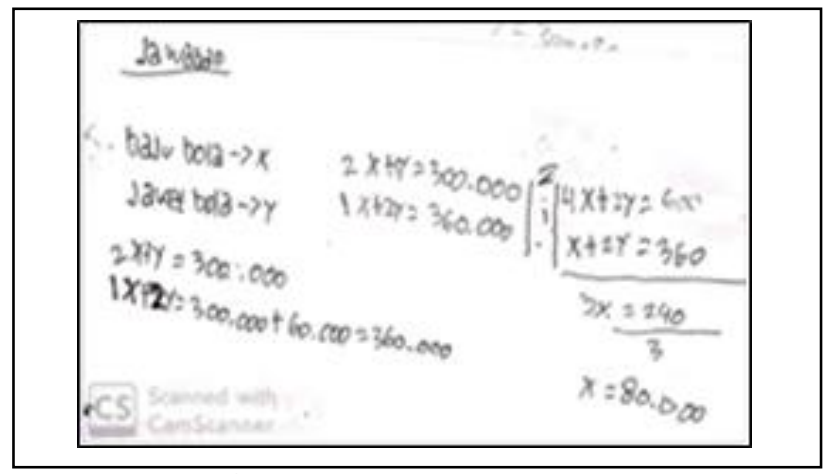

Picture 1 Student Ans wer question number 1

Based on students answers on number one, students already understand the problems asked by changing the story into the form of mathematical modeling equations but students have difficulty when using elimination methods on the linear equation system so that the result of what the question does not provide the right.

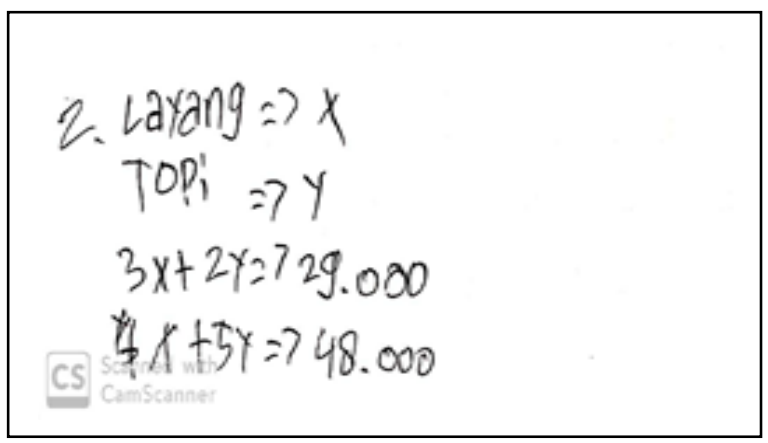

Picture 2 Student Answer question number 2 
Based on the students answers to question number two, it shows that the students responses are good, it can be seen from the students taking the kites and hats with variables, this is the process of changing a normal problem into a mathematical model. But students are lacking in working on the problem / incomplete, because in questions other than changing the story into a mathematical model students must be able to determine the price / value of kites and hats

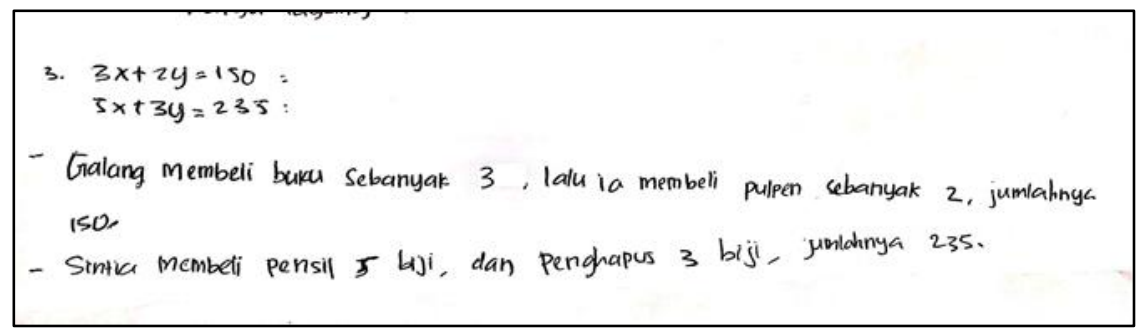

Picture 3 Student Answer question number 3

In question number three, students are asked to determine the values of $\mathrm{x}$ and $\mathrm{y}$ and change the equation into the form of story questions, but based on students answers, students do not look for the values of $\mathrm{x}$ and $\mathrm{y}$ in accordance with the questions asked and students change the equation into the form of story questions, but story questions that students have arranged fairly train students in copying and making problems, the lack of students in compiling the story problems there are no problems or are asked. So the question of the story arranged by students is just an ordinary

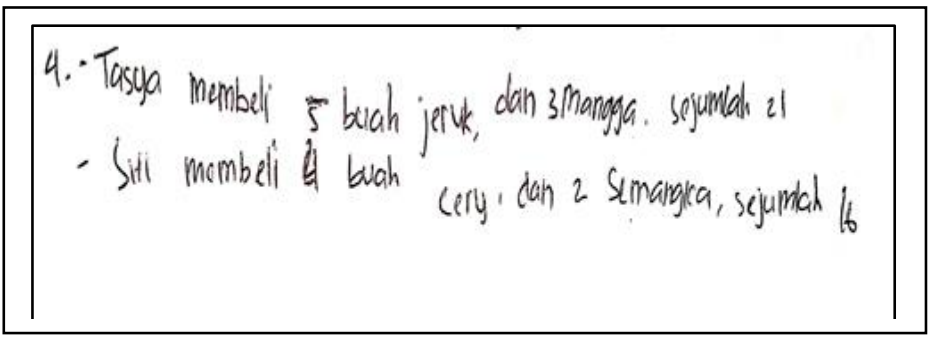

Picture 4 Student Ans wer question number 4

Based on problem number 4 students are asked to make a story problem from a predetermined equation, and seen from the students' answers, students have responded and worked on it according to the instructions, but students did not add what they asked.

\section{CONCLUSION}

Based on the results of the analysis of the mathematical communication skills of Grade VIII Middle School students are categorized as moderate with a percentage of $42.5 \%$ obtained from the overall results of the percentage of each item divided by the number of questions worked on. Mathematical communication skills of students of the ten students observed, it turns out that the ability of students is very homogeneous starting from students who respond and communication is inefficient and answers are empty / not working, students with good response and communication criteria, and less complete in answering problems, students who response, communication and answer questions well but the presentation is lacking and not writing examples there are also students who respond, communicate, and present completely but students do not write examples. To 
improve students' communication skills the need for routine exercises with students is often invited to discussions and groups during the learning process.

\section{REFERENCES}

Andayani, F. (2019). Analisis kemampuan pemecahan masalah siswa smp dalam menyelesaikan soal pada materi aritmatika sosial. Jurnal Pendidikan Matematika, $3(1), 1-10$.

Hajar, M. S., \& Zanthy, L. S. (2008). Analisis Kesalahan Kemampuan Pemecahan Masalah Matematika Siswa MTs. On Education, 1(2), 99-104.

Martini, S., \& Al, E. (2018). Pengaruh Pendekatan Realistik Terhadap Kemampuan Komunikasi dan Self Confidence Siswa SMP. Jurnal Pembelajaran Matematika Inovatif, 1(2), 149-156. https://doi.org/10.22460/jpmi.v1i3.219-228

Purwasih, R. (2015). Peningkatan Kemampuan Pemahaman Matematis Dan Self Confidence Siswa MTs Di Kota Cimahi Melalui Model Pembelajaran Inkuiri Terbimbing. Didaktik, 9(1), 16-25. Retrieved from http:/lejournal.stkipsiliwangi.ac.id/index.php/didaktik/issue/view/18

putri, panca, S. (2018). Analisis Kesulitan Belajar Siswa Dalam Menyelesaikan Soal Jurnal Penyesuaian Pada Mata Pelajaran Ekonomi. Neraca, 2(2), 97-107. https//doi.org/10.1017/CBO9781107415324.004

Rahayu, T. D., Purnomo, B. H., \& Sukidin, S. (2014). Analisis Tingkat Kesukaran Dan Daya Beda Pada Soal Ujian Tengah Semester Ganjil Bentuk Pilihan Ganda Mata Pelajaran Ekonomi Kelas X Di Sma Negeri 5 Jember Tahun Ajaran 2012-2013. Edukasi, 1(1), 39-43. Retrieved from https $/ /$ jurnal.unej.ac.id/index.php/JEUJ/article/view/1032/829

Rahmawati, N. S., Bernard, M., \& Akbar, P. (2018). Analisis Kemampuan Komunikasi Matematik Siswa Smk Pada Materi Sistem Persamaan Linier Dua Variabel (Spldv. Journal On Education, 1(2), 344-352.

Sari, A. M., Susanti, N., \& Rahayu, C. (2018). Analisis kesalahan siswa dalam menyelesaikan soal cerita materi aritmatika sosial kelas VII. Jurnal Penelitian Dab Pengajaran Matematika, 4(2), 61-62.

Wijayanto, A. D., Fajriah, S. N., \& Anita, I. W. (2018). Analisis Kemampuan Komunikasi Matematis Siswa Smp Pada Materi Segitiga Dan Segiempat. Cendekia: Jurnal Pendidikan Matematika, 2(1), 97-104. https://doi.org/10.31004/cendekia.v2i1.36

Yuniarti, N., Sulasmini, L., Rahmadhani, E., Rohaeti, E. E., \& Fitriani, N. (2018). Hubungan Kemampuan Komunikasi Matematis Dengan Self Esteem Siswa SMP Melalui Pendekatan Contextual Teaching And Learning Pada Materi Segiempat. Jurnal Nasional Pendidikan Matematika, 2(1), 62-72.

Zanthy, L. S. (2016). Pengaruh Motivasi Belajar Ditinjau Dari Latar Belakang Pilihan Jurusan Terhadap Kemampuan Berpikir Kritis Mahasiswa Di STKIP Siliwangi Bandung. Jurnal Teori Dan Riset Matematika, 1(1). 